\title{
Psychosocial Aspects of Quarantine, Social Isolation and Social Distance
}

\author{
José Carlos Souza1 ${ }^{10}$, Elaine Cristina Pettengill², Carlos Alfredo Pettengill ${ }^{3}$ \\ ${ }^{1}$ Universidade Estadual de Mato Grosso do Sul (UEMS), Campo Grande-MS, Brasil \\ ${ }^{2}$ Centro Universitário Unigran Capital, Campo Grande-MS, Brasil \\ ${ }^{3}$ Escola Municipal José Rodrigues Benfica, Campo Grande-MS, Brasil \\ Email: josecarlossouza@uol.com.br, elapettengill@hotmail.com, carlospettengill@gmail.com
}

How to cite this paper: Souza, J. C., Pettengill, E. C., \& Pettengill, C. A. (2020). Psychosocial Aspects of Quarantine, Social Isolation and Social Distance. Psychology, 11, 1200-1214.

https://doi.org/10.4236/psych.2020.118080

Received: July 25, 2020

Accepted: August 24, 2020

Published: August 27, 2020

Copyright (C) 2020 by author(s) and Scientific Research Publishing Inc. This work is licensed under the Creative Commons Attribution-NonCommercial International License (CC BY-NC 4.0). http://creativecommons.org/licenses/by-nc/4.0/

\section{(c) (i) \$ Open Access}

\begin{abstract}
To discuss the psychosocial aspects of the quarantine, the distance and social isolation during the new coronavirus pandemic, they represent a risk to the mental health and the aspects that act as a protective factor for the psyche health. This was made through integrative review of publications in the last five years, the bibliographic databases PubMed, Lilacs and Scielo, also considering the psychoanalytical classics of the literature. It was observed that the deprivation of social interaction and the restricting freedom can represent for a lot of people a real blow to their narcissism, an affront to their free will on account of the unconscious meaning that this experience can be. The resilience and the sense of empathy can foster the well-being of people and encourage attitudes of care and protection of the other. Finally, this study contributes as a theoretical tool to scientifically support strategies for mental health prevention and health promotion of the psyche.
\end{abstract}

\section{Keywords}

Social Isolation, Quarentine, Psychosocial Aspects, COVID-19, Mental Health

\section{Introduction}

In January 2020, the World Health Organization (WHO) declared a Public Health Emergency of International Importance due to the occurrence of a crisis of severe acute respiratory disease that out broke in the province of Hubei, China, country that concentrated approximately $99 \%$ of the cases occurred worldwide till February 12th, 2020. This respiratory disease is caused by the 
new coronavirus, which was possibly transmitted, at first, through the consumption of wild animal's meat in Wuhan, in China, and later transmitted by person-to-person contact in other regions of China and in other countries.

With more than 1,677,256 cases confirmed on April 10, 2020, and 101,732 deaths, according to Johns Hopkins University data (Johns Hopkins Medicine, 2020), the main features of this coronavirus epidemic are an incubation period from 0 to 24 days, which may vary from 1 to 12.5 days following WHO (World Health Organization, 2020). As coronavirus contagion risk has been increasing transforming it in to public health issue, as it is a pandemic, the Brazilian federal government and the world, in compliance with WHO guidance, have decreed the restriction or social distancing, quarantine and social isolation.

There are several tools to prevent disease's spread: the social distancing implies physical separation, social isolation is separation of sick people with respiratory symptoms, suspected, or confirmed cases of coronavirus and quarantine are designed to control activities or separate people who were exposed to the coronavirus that are not sick (i.e., they were not infected or they are in the incubation period of the disease) (Telessaúde, 2020).

Nevertheless, social isolation, social isolation and quarantine result in a collective traumatic event that represents a serious menace to people and has harmed life and properties (Mukhtar, 2020). According to Minayo, Teixeira and Martins (2016), social isolation causes the feeling of boredom that can encourage the feeling of despair and motivate impulsive attitudes, such as the suicidal act and attitudes of hetero aggressive behavior. Studies also point out that, as responsible for the perception of isolation from the rest of society, distressing feelings are constantly related because of the deprivation of usual practices, such as participating in social and visiting family and friends, thus that raises levels of stress, anxiety (De Lima et al., 2020), premature mortality, depression, and cognitive decline. Therefore, endeavor should be directed to reduce the negative effects of this strategy of prevention (Smith \& Lim, 2020).

\section{Objective}

To discuss the psychosocial aspects of quarantine, social distancing and social isolation during the new coronavirus pandemic, which represents a risk to mental health and the factors that protect the health of the psyche.

\section{Method}

It was made based on an integrative bibliographic review using SciELO, Lilacs, PUBMED and Virtual Libraries of Brazilian Universities databases, using the following keywords in Portuguese: "isolamento", "isolamento social", "saúde mental”, "psiquismo", "interação social”, "prejuízos”, “COVID-19”, "resiliência” and "autonomia". Besides, classic literatures of psychoanalysis and philosophy have been included. Although 35 related articles to isolation were found, just 12 of them were selected. As inclusion criteria we only used articles published dur- 
ing the last 5 years that discussed psychological aspects related to social isolation, articles published over 5 years and those discussing psychological aspects related to social phenomena other than isolation were excluded.

\section{Results}

The need to distancing, social isolation and remain in quarantine to prevent coronavirus contagion has generated considerable dissatisfaction and anguish in the population, as observed among patients seen by professionals in Psychiatry and Psychology at Campo Grande-MS city. Based on the results of several studies focus on analyzing the consequences of social isolation and confinement for mental health (Table 1), It will be discussed the risk psychosocial factors and health protection factors of the psyche under the circumstances of quarantine and restriction/social isolation related to the prevention of COVID-19.

In a study focus on the risk of suicide in institutionalized seniors, Minayo, Teixeira and Martins (2016) refer to a 60-year-old participant who attempted suicide twice due to the feeling of loneliness, family absence, isolation and see no meaning in life. Daniel et al. (2019) analyzed the representations that institutionalized seniors have on the residential structures they inhabit.

People interviewed shared the dominant social representations associate with the residential structure for the seniors to negative elements. Indeed, in several speeches terms such as "prison", "another world", "cemetery" or "end" emerged.

Social isolation was also shown to be related to the feeling of loneliness, symptoms of depression and impaired self-esteem, among patients with exudative neoplastic wounds, i.e., skin lesions that can develop on oncological patients from infiltration of the tumor, by accidental implantation of malignant cells in the skin during surgical procedures, diagnosis or by metastasis of the skin tumor in the skin compositions. These injuries, according to the researchers, are characterized by pain, foul odor, bleeding, infection and exudate, resulting in the frequent need for clothing and bulky dressings, favouring social isolation to avoid derogatory comments that damage your personal identity (Santos et al., 2017).

\section{Discussion}

It is known that the seniors are part of the risk group with regard contagion by the coronavirus and for better protection is essential that they remain physically distant from their family and friends, as you never know who is or is not infected by this virus since infected person may not present the symptoms but may transmit the virus to others. Seniors as a result, can develop feelings of loneliness and family absence, which can progress to depressive symptoms (if predisposed), representing a risk for mental health. These feelings can be aggravated when the family of the Seniors is unable to establish the necessary affective closeness with their Senior via internet or telephone, keeping themselves emotionally distant from them. 
Table 1. Research about the consequences of social isolation and quarantine for mental health.

\begin{tabular}{|c|c|c|c|}
\hline \multicolumn{4}{|c|}{ Results of Several Studies } \\
\hline Authors & $\begin{array}{c}\text { Year of } \\
\text { publication }\end{array}$ & Experimental design & Outcomes \\
\hline $\begin{array}{l}\text { Minayo, } \\
\text { Teixeira and Martins }\end{array}$ & 2016 & $\begin{array}{l}\text { Case study ( } 60 \text {-year-old man) about the risk } \\
\text { of suicide in institutionalized Senior. }\end{array}$ & $\begin{array}{l}\text { Risk factor for the Senior: feeling of } \\
\text { not seeing meaning of life. }\end{array}$ \\
\hline Daniel et al. & 2019 & $\begin{array}{l}\text { Qualitative study of the representations that } \\
\text { institutionalized Seniors have on the residential } \\
\text { structures they inhabit. Eighteen Seniors } \\
\text { interviewed from a Seniors institution. }\end{array}$ & $\begin{array}{l}\text { People interviewed shared the dominant social } \\
\text { representations that associate the residential } \\
\text { structure for the elderly with negative elements. } \\
\text { Indeed, in the varied terms such as "prison", } \\
\text { "another world", "cemetery" or "end" were } \\
\text { manifested in plenty speeches. }\end{array}$ \\
\hline Santos et al. & 2017 & $\begin{array}{l}\text { Identify the scientific evidence on social } \\
\text { isolation in patients with exudate in } \\
\text { neoplastic wounds. Integrative Review Study. }\end{array}$ & $\begin{array}{l}\text { These injuries, according to the researchers, } \\
\text { are characterized by pain, unpleasant smell, } \\
\text { bleeding, infection and exudate, resulting in the } \\
\text { frequent need for clothing and the use of bulky } \\
\text { dressings, favoring social isolation to avoid } \\
\text { derogatory comments that damage their identity. }\end{array}$ \\
\hline Miguel et al. & 2018 & $\begin{array}{l}\text { Quantitative research to the validation of } \\
\text { empathy online questionnaire. }\end{array}$ & $\begin{array}{l}\text { Empathy is strongly related to care in contact } \\
\text { with other people, a concern to be pleasant and } \\
\text { worry more about the way you treat others. }\end{array}$ \\
\hline Lopes et al. & 2015 & $\begin{array}{l}\text { Qualitative research whose objective was to } \\
\text { understand aspects of the experience and } \\
\text { family background of the person who } \\
\text { consumes alcohol and is not under treatment. }\end{array}$ & $\begin{array}{l}\text { The participant's testimonies reveal a great suffering } \\
\text { from families and users due to the consumption and } \\
\text { abuse of alcoholic beverages, leading to disrespect, } \\
\text { violence, negative feelings towards the abusive family } \\
\text { member affecting all members. }\end{array}$ \\
\hline Indursky and Conte & 2015 & $\begin{array}{l}\text { Qualitative research. Considerations about } \\
\text { the experience of therapeutic intervention } \\
\text { conduce by the United Nations } \\
\text { High Commissioner for Refugees (UNHCR) }\end{array}$ & $\begin{array}{l}\text { In exile, as well as in loss situations, there is a feeling } \\
\text { of real absence (city/country, family, network and } \\
\text { social function) which is later invested as a symbolic } \\
\text { object (the homeland, for example), characterizing } \\
\text { deprivation as the engine in the function of } \\
\text { reorganizing narcissistic and object investments. }\end{array}$ \\
\hline Margaça and Rodrigues & 2019 & $\begin{array}{l}\text { Integrative Review Research whose } \\
\text { objective was to discuss spirituality as } \\
\text { a factor of resilience promotion in } \\
\text { adulthood and Seniors. }\end{array}$ & $\begin{array}{l}\text { Spirituality and religiosity have been identified as } \\
\text { an important influencing factor on the significance } \\
\text { of suffering related to chronic illness or as a resource } \\
\text { of hope while facing changes in health status over } \\
\text { the years of life. Spirituality is also related to the } \\
\text { capacity for resilience. }\end{array}$ \\
\hline Padovani and Ristum & 2016 & $\begin{array}{l}\text { Qualitative Research whose objective was } \\
\text { to understand how adolescents who } \\
\text { committed an infraction, fulfilling a } \\
\text { socio-educational measure of hospitalization, } \\
\text { mean hospitalization. }\end{array}$ & $\begin{array}{l}\text { The participants identify hospitalization as } \\
\text { punishment, suffering, social isolation, family } \\
\text { distancing; however, they also tried to realize the } \\
\text { positive aspects, such as care, respect, the } \\
\text { possibility of studying and becoming professional. }\end{array}$ \\
\hline Seidl-de-Moura & 2017 & $\begin{array}{l}\text { Qualitative Research whose objective was to } \\
\text { analyze the beliefs and conceptions about } \\
\text { autonomy in different age groups. }\end{array}$ & $\begin{array}{l}\text { The categories "Independence" and "Sense of } \\
\text { freedom" were at the heart of the conceptions of an } \\
\text { autonomous person in the group of participants and } \\
\text { show some stability in different age groups. So, } \\
\text { according to the authors, a notion of an autonomous } \\
\text { person for the group, regardless of age, as someone } \\
\text { who has the ability to manage their life and has no } \\
\text { limitations or restrictions on their thinking and acting }\end{array}$ \\
\hline
\end{tabular}




\section{Continued}

\begin{tabular}{|c|c|c|c|}
\hline Schmid & 2019 & $\begin{array}{l}\text { Qualitative Research (Case study). } \\
\text { Six months experience report as a psychiatrist } \\
\text { by Médecins Sans Frontières (MSF), in a } \\
\text { refugee detention center located in Nauru, } \\
\text { an island country in Oceania. In this study, } \\
\text { the author discusses the topic of suicide and } \\
\text { the specificity of this issue for the group of } \\
\text { refugees and asylum seekers served, as well as } \\
\text { reporting the discovery of a new clinical } \\
\text { diagnosis called resignation syndrome. }\end{array}$ & $\begin{array}{l}78 \text { of the patients treated by MSF had suicidal ideas } \\
\text { and/or performed acts of self-mutilation or suicide. } \\
\text { hopelessness was the guiding thread for suicidal } \\
\text { ideation and suicide attempts. Yet, the author's } \\
\text { listening exercise during consultations with reports of } \\
\text { suicidal ideation, or acting in suicidal acts in Nauru, } \\
\text { made possible to understanding of a singular feature } \\
\text { of suicide for these refugees: the suicide revealed } \\
\text { as an act of re-empowerment. }\end{array}$ \\
\hline $\begin{array}{c}\text { Domingues-Castro } \\
\text { and Torres }\end{array}$ & 2018 & Integrative Review on Hikikomori. & $\begin{array}{l}\text { Hikikomori is a serious phenomenon of prolonged } \\
\text { and voluntary social isolation, in which the subject } \\
\text { presents losses in the bond with the family due to } \\
\text { the altered pattern of sleep, eating problems, } \\
\text { authoritarian attitudes, compulsive, destructive and } \\
\text { violent behaviors, behaviors fostered by social } \\
\text { isolation. }\end{array}$ \\
\hline
\end{tabular}

Another risk factor for the Seniors is the feeling of no sense of life, as reported by Minayo, Teixeira and Martins (2016) studies. Some Seniors, especially females, according to the clinical experience from assistance provided in the areas of Psychology and Psychiatry, unable to leave home, they are not performing productive activities such as manual work (crochet and knitting; handcraft) due to the lack of raw material, situation that get worse when Senior women cannot count with family members help who could acquire the raw materials in their place, since family members do not show availability or interest, fostering feelings of abandonment, loneliness and impotence.

Miguel et al., in a study on the validity of the online empathy questionnaire, indicated that this feeling is strongly related to care in contact with other people, to a concern over being pleasant and being more concerned of how to treat the others (Miguel et al., 2018). Preventive care against the contagion of COVID-19 requires enough individual empathy, enabling each person to understand that everyone is afraid of becoming ill and then start to be worry about not to offer risk to others through negligent behavior, as well as, through empathy, each individual can put himself in the other person place regard the relative suffering, the own social isolation, seeking to fell affective and attention needs with each other despite the physical distance.

The social distance resulting of the need for prevention against the coronavirus, led many families to share much longer time than they used to before the pandemic, representing an opportunity to strengthen affective bonds between family members who were more distant by the lack of time or intimacy, but which may also have caused considerable tension in many family environments, as in families where some of its members abuse of alcohol.

Lopes et al. (2015) carried out a study aiming to learn the aspects of the experience and family context of the person who consumes alcoholic beverages who are not under treatment. Participants' speeches revealed great personal and fam- 
ily suffering due to the consumption and abuse of alcoholic beverages, leading to disrespect, violence, negative feelings to the family member who drinks and reflecting negative over all members. This is aggravated when, in the impossibility of leaving home and finding people to lean on to face the family member's drinking problem, the individual needs to remain in the family environment and witness the family's drunkenness, which can generate great discomfort and suffering.

Starting from the therapeutic work offered by a psychoanalytic institution located in Porto Alegre (RS), in associated with the United Nations (UN), psychoanalytic treatment is available to refugees, victims of violence and persecution, who arrive to Brazil treated as refugees for the United Nations High Commissioner for Refugees (UNHCR). Indursky and Conte (2015) present in their study considerations about the therapeutic intervention performed with these individuals. As a result, the authors observed that in exile, as well as in situations of loss, lack of something real is present (city/country, family, network and social function) that is soon invested as a symbolic object (e.g., the homeland), featuring deprivation as the engine to the work of reorganizing narcissistic investment and object.

Thus, quarantine experiences, isolation and social distance related to the coronavirus, represent psychic experiences of loss, the loss of freedom, the possibility of social encounters in a specific space without fear of infect or be infected by the coronavirus, a loss that requires a reorganization of libidinal investments made in the lost experiences (face-to-face meetings and activities carried out in person and not online). Under the mourning related to the losses, the subject needs, to keep his mental health preserved, to reinvest his libido in other forms of social contact, creating new possibilities for interaction and for search satisfaction in life. Segal (1975) states that the possibility that a person has to deal satisfactorily with situations of loss, is closely related to the mourning that he was able to overcome with considerable success in his childhood. Klein (2012) considers "successful mourning" the psychic experiences in which the child was able to conclude (throughout his childhood) that, despite all the damage he may have imagined caused to his objects of love (his parents), they survived to all the possible destructive (imaginary) attacks. Consequently, they could be introjected into good condition, signaling to the child that the repair mechanisms psychically used by himself while facing the damage he caused were successful (Klein, 2012).

The quarantine experience related to the coronavirus tends to be an experience that by itself generates persecutory anxieties because the individual is in a state of expectation about whether or not he is infected with COVID-19. Klein (1946) exposes that facing situations that generate persecutory anxieties or retaliation, more immature peoples ego or seriously mentally compromised, tends to use very primitive defensive mechanisms, called by Klein as mechanisms of a psychotic nature, which are mechanisms used very often during the first months of life, when the baby's mind is still unable to handle considerable amounts of 
tension, tending to project this tension out in addition to other ways to defend itself from anxiety.

Thus, in front of intense persecutory anguish caused by the fear of being infected by COVID-19, the subject in quarantine can use psychotic defensive mechanisms and then suffer and bring harm to other people due to the consequences of using such mechanisms. One of these mechanisms is Projection, causing the subject to project (in other people) his feeling of helplessness and fear while facing the situation, becoming excessively uncomfortable with the feeling of helplessness and fear that he then believes that other people they are presenting, without realizing that in fact himself (also) is scared and feeling powerless but that he cannot deal with these feelings due to his egoic fragility.

Successful experiences of childhood mourning are fundamental for the child to develop feelings of gratitude and hope, which are important feelings for the human being to face the adversities of life with willingness, perseverance and motivation to seek possibilities of resolution for the problems faced. As from Klein (2012)'s studies, it is possible to conjecture that people who managed to nurture the feeling of hope throughout their childhood from satisfactory experiences of reparation (prevalence of gratifying experiences in detriment of frustrating experiences over the parents bond). In the same way, nowadays, in facing of the coronavirus pandemic and the consequent need for distance and social isolation, they are more likely to assume attitudes of optimism and resilient facing in front of the naturally arising anxieties.

The feeling of gratitude, which also develops from these childhood experiences, will enable the subject in the different stages of life to be able to enjoy the feeling of happiness, as he is able to recognize and value happy and satisfying moments when happen. Thus, also based on the theoretical findings of Klein, it is argued that people who were able to nurture gratitude in their childhood, today when facing the pandemic, are more likely to be able to value and enjoy what, as far as possible, can bring happiness (Klein, 2012). Thus, the predominance of rewarding experiences (and restorative) over the detriment of frustrating or traumatic experiences throughout childhood, is a protective factor for mental health to face problems and adversities, such as the current pandemic moment.

Indursky and Conte (2015) also observed, at least in the first period of exile, that the displacement in space often represents (especially to older individuals) a restitution of their lost history. However, in the clinical experience of analytical psychotherapy, it is noted that some patients are too distressed by this displacement in space (moving their jobs to the home dependencies), with great difficulties to experience this mourning for what they are losing and sometimes reacting with great revolt and episodes of aggression, with important detriment in the interaction with the family. These authors also checked that, when the ego is unable to examine the current situation due to the excess of reality, the libidinal recomposition in a new object is interrupted, the narcissistic investment takes the body direction and appears a "language" that communicates that something painful is besieged in the body and not in symbolic substitutes (In- 
dursky \& Conte, 2015). The body appears as the last refuge that the subject can use, and then the person can develop the psychosomatic diseases (Mc Dougall, 1994).

According to Indursky and Conte (2015), in detriment of envelopes providing spatiality to psychic contents, the body will serve as a container. These studies observed a great difficulty for refugee to get in touch with their anxieties and fear for the risk of a psychological breakdown in form of psychosomatic illnesses or suicide attempts, which can also happen to people who find difficulty to deal with anxieties raised from social isolation, quarantine and social distance related to COVID-19. These people need to find ways to identify and to name their anxieties, which occurred efficiently in psychoanalytic psychotherapy (Mc Dougall, 1994).

Patients under this therapeutic approach have the chance to perform what Bion (1972) called emotional literacy with his psychotherapist, in which through the bond with the therapist the patient has the opportunity to name anguish that he is unable to deal (to identify and to name), and this "nameless terror". However, if it does not, according to Bion (1972), this is a factor risk for the mental health, increasing the chances not only to suicide attempts, but also to psychosomatic manifestations. Thus, psychotherapy, which does not necessarily have to be psychoanalytically oriented (since any psychotherapy, in fact, is capable of providing insights of the psychological functioning to the patients), is a protective factor for mental health for many people, especially at this pandemic time characterized by social restriction and isolation. Psychotherapy with these patients, also aims at this moment, to provide insights (and a related catharsis) regarding their difficulties of dealing with feelings around all they are losing with isolation, quarantine and social distancing, as well as the possible gains that this experience brings.

Heidegger (1927), in a reflection on Dasein, (being in the world) presents the panorama of language as a manner for human beings to be and be in the world. The relationship that can be inferred between the ego defensive mechanisms, from Freudian psychoanalytic theory and the logos (i.e., language) is found in the presence and absence of the discourse (Freud, 1977). In this way, the silence that isolation provoks may be causing fear, deny and believe, permeates those who use these verbs (that may or may not be reflected) the presence of a meaning. Besides, in cases of illness, conscious seek the other because maybe it is there, that he will find himself and the reality of finitude, inherent to living beings. For the philosopher Nietzsche (2008), loneliness allows the human being to meet himself, making it possible to distance himself from the social masks he uses in social life and by separating what would not be from the subject, promotes the creation of himself, for that who is coming in another perspective, in another logic that differs from the herd logic.

From this study it is noted that the external reality (in addition to the internal reality of each subject, their psychological world) also seems to have influenced the perception of the experience of isolation. Thus, it becomes possible that the 
experience of social distancing related to the prevention of COVID-19 may be perceived as "poison" (mentioning the young man from the Padovani and Ristum (2016) survey for a good portion of the Brazilian population, who live in a situation of misery, in very small houses and with a large number of people who cannot enjoy privacy. In wealthy families, there is a possibility, even in a situation of deprivation of social interactions and the need to remain at home, subjects enjoy some privacy because each member of these families often has their own room, their TV, their computer, in addition to other means of leisure and that promote well-being as a leisure area, own gym, among other resources that can contribute to the protection of quality of life and that necessarily imply a good socio-economic reality.

The possibility of recognizing possible gains from a difficult experience can bring (e.g., the experience of social isolation) contribute one of the aspects of the resilience capacity that a person can have. In a study that discussed spirituality as a factor to promote resilience in adulthood and Seniors, was checked that spirituality and religiosity have been identified as an important influential factor on the meaning of suffering related to chronic disease or as a resource of hope in facing changes in health status over the years of life (Margaça \& Rodrigues, 2019). Furthermore, they exposed that spirituality is also related to the capacity for resilience. It can works as a mediator for the individual in stressful moments, motivating the subject to adapt to the difficult reality (create adaptation strategies), to adjust to it in the best possible way. Religious and spiritual beliefs can function as protective factors in stressful situations, enabling great resilience even facing loss situations, such as the loss of freedom that social distancing, quarantine and social isolation are causing. These behavioral features (i.e., resilient in front of the need for social distance related to the coronavirus) can be observed in the psychological clinic, among religious patients.

It is known that resilience and the ability to glimpse new possibilities and find creative solutions while facing a difficult reality, it can be seen in this study by Padovani and Ristum (2016), whose aim was to understand how teenagers who committed an infraction, fulfilling a socio-educational measure of hospitalization, mean hospitalization. When capture the significant aspects of the hospitalization unit, teenager revealed hospitalization as punishment, suffering, social isolation, family distance. However, they also tried to make its positive aspects visible (e.g., care and respect). This ability to perceive and consider the positive aspects of the hospitalization experience (implied in social isolation or restriction), reflects the resilience of these young people who, despite the frustrating experience of hospitalization, made good use of this experience, overcoming the anxieties that naturally raised by confinement. However, Padovani and Ristum (2016) address another issue that also seems to have influenced this positive attitude towards hospitalization. According to the authors, this particular institution (where the research was conducted) is a space that allows young people to enjoy leisure (including a swimming pool), good food and comfort in general, with a wooded and flowery square and preserved architecture, enabling young 
people to experience well-being in terms of physical space. The authors cite the report of a young intern, regarding one of his previous hospitalizations because of committed crimes, calling the old hospitalization as "poison" when compared with the current institution where he was in.

Regarding the possibility of choosing to remain optimistic, with hope and motivated to carry out domestic labours, professional tasks, children care (e.g., children parents), among other commitments, during social distance, quarantine and isolation (related to coronavirus), Costa and Gomes (2017) refer to this choice as a psychoanalytic conception and a restricted choice since. To the psychoanalytic precepts, the human being is not entirely free to make his choices, with influence over all his attitudes by unconscious aspects, such as impulses, aggressive and sexual repressed desires, fantasies, traumatic and pleasant childhood experiences. These authors assert that it is possible to try to establish contact with these aspects of the unconscious (e.g., through psychoanalytic treatment) to conquer some control over these unconscious variables, in order to experience the feeling of certain control over their choices since it is able to recognize the unconscious aspects related (Costa \& Gomes, 2017). Thus, people who adopt a pessimistic stance, hopelessness or even despair facing the isolation need, quarantine and social distance, are not freely choosing this position. According to psychoanalytic assumptions, they can be helped by mental health professionals (clinical psychologists/psychotherapists) about changing ways of dealing with the problem.

Parallel to this defensive mechanism, the subject also tends to use the Denial mechanism, which can lead him to behave while facing the quarantine that the risk of infection is very distant from him, and he may believe that people are being exaggerated when request him to remain in isolation, which favors attitudes of negligence of this person, exposing others to the risk of contagion. Idealization, according to Klein (1946) studies, is a commonly used mechanism in conjunction with Denial, and can cause the subject in quarantine to present an excess of optimism, often manifested by the belief that a miracle will happen to him or the belief that someone (e.g., a religious leader) or something (e.g., objects invested with mystical power) can cure him, and may even culminate in delusions or delusional ideas of greatness and superiority in relation to other people, believing that his body is immune to the coronavirus because it is blessed by God or that he was chosen by God to be saved from the coronavirus, making it difficult to adhere to the care needed to keep in quarantine.

In a study with the aim of analyze the beliefs and conceptions about autonomy in different age groups, Seidl-de-Moura et al. (2017) verified that the categories Independence and Sense of freedom were at the heart of the conceptions of an autonomous person in the group of participants investigated and show some stability in different age groups. Therefore, a notion of an autonomous person for the group (regardless of age) as someone who has the ability to manage their life and has no limitations or restrictions on their thinking and acting. Starting at this conception of autonomy, it is understandable that many people today, due 
to the need for distance, social isolation and quarantine, may be feeling castrated in their freedom to come and go without risk of any harmful consequences (becoming infected and infect other people with the coronavirus), which represents a risk to mental health since the feeling of castration, for some people much more than for others, tends to generate discontent and depressive anxieties that can culminate in the development a mental disorder such as depression and impulsive behaviors such as suicide attempted.

In addition, in front of such anxieties, is also possible that some react in manic manner (Klein, 2012), expressing total indifference to the need to protect themselves and to protect others from the contagion of the coronavirus. The current feeling of castration can mobilize in some people (especially for those who have experienced intense childhood oedipal conflicts and which have been unsatisfactorily developed) the anguish and the childhood complex of castration, increasing the discomfort that social isolation and freedom restriction naturally provoke.

Schmid (2019) revels a six months experience as a psychiatrist for Doctors without Borders (MSF) in a refugee detention center located in Nauru, an island country in Oceania. In this study, the author discusses the suicide and the specificity of this issue for the group of refugees and asylum seekers served, as well as reporting the discovery of a new clinical diagnosis called resignation syndrome. Schmid observed that at least 78 of the patients treated by MSF had suicidal ideas and/or performed acts of self-mutilation or suicide (Schmid, 2019). He verified that hopelessness was the guiding thread for suicidal ideation and suicide attempts. Yet, the author's listening exercise during consultations with reports of suicidal ideation, or acting in suicidal acts in Nauru, made possible to understanding of a singular feature of suicide for these refugees: the suicide revealed as an act of re-empowerment. This suicide feature, as a recovery of power, strongly impacted his research. According to Schmid, detained for five years in Nauru, refugee patients expressed, in the discussion about their own death, the only possibility of protest and affirmation of some decision-making power over themselves (Schmid, 2019).

In this sense, it is possible that people who present a Narcissistic Personality Disorder, a Challenge and Opposition Disorder and other psychopathological manifestations that reflect the great difficulty of the subject to deal with the feeling of castration (Freud, 1905) that is fostered by the restriction of freedom and social isolation (due to the coronavirus), seek in the suicide attempt the empowerment that was removed from them with the need for quarantine or isolation. Schmid (2019) also observed, among refugees, the development of psychopathologies such as Posttraumatic Stress Disorder (PTSD), especially among children, PTSD with psychotic features and the "Resignation Syndrome (SR)" (Schmid, 2019). The author states that the refugees (and their patients) started resignation chart with depressive symptoms, evolving with suicidal ideation, episodes of psychomotor agitation, alternating with a stuporous chart marked by hypotonicity. The chart continuity was with complete lack of responsiveness 
without reactivity to tactile or painful stimulus and rejection on food and liquids, ending in the need for evaluation to nasogastric intubation.

It is important to emphasize that, in this period of social distancing, quarantine or social isolation, people who present depressive syndromes should be supervised by their family members regarding adherence to treatment (medication and psychotherapeutic), as their condition may evolve to other serious psychopathological conditions that also offer risk of death, such as the resignation syndrome, which, according to Schmid, can affect individuals in circumstances of restriction and loss of freedom or isolation from social interactions (Schmid, 2019).

The real "hygiene rituals" that are currently necessary to prevent contagion by the coronavirus, may leave psychological consequences in people who are predisposed to diseases such as obsessive compulsive disorder and phobias related to the fear of being infected by viruses and bacteria, among others phobias, as well as turn in to a risk factor for disorders that reflect prejudice in the ability to interact socially, such as Hikikomori disorder. According to Domingues-Castro and Torres (2018), Hikikomori is a serious phenomenon of prolonged and voluntary social isolation, in which the subject presents losses in the bond with the family due to the altered pattern of sleep, eating problems, authoritarian attitudes, compulsive, destructive and violent behaviors, behaviors fostered by social isolation. Although social isolation motivated by the need to prevent coronavirus is not voluntary, deprivation of social contacts and long-term social distance may favour attitudes of reduce tolerance and heteroaggressiveness in individuals already predisposed to these behaviors.

\section{Study limitations}

As it is still a very recent phenomenon, studies focusing on the psychic effects of quarantine, isolation and social distancing related to the new coronavirus. Thereby, it was necessary to find theoretical support on studies dealing with the three referred phenomena in other circumstances.

\section{Contributions to Nursing, Health or Public Policy}

This study can contribute as a theoretical tool for understanding the different manifestations of behavior that reflect the psychological suffering of the subjects who feel emotionally affected because of the need to restrict social contacts or the isolation itself, as well as to scientifically support strategies for prevention and health promotion, even in circumstances of quarantine or restriction and isolation from social interactions.

Due to the need to prevent the spread of the coronavirus, health Brazilian and worldwide professionals have been called to adopt strategies that encourage constant hygiene care in the population to avoid contamination by COVID-19, in order to also contribute to nation's Health System, by delaying the rise of the disease among people in different locations as much as possible. In the case of 
mental health professionals, contributions may occur at different levels of prevention (primary, secondary and tertiary) and the present study contributes mainly at the primary and secondary levels of prevention by offering itself as a theoretical instrument for the reflection on the psychological aspects involved in both, the processes of mental illness and the processes of maintaining the health of the psyche while facing the reality of social isolation.

\section{Final Considerations}

The risk factors for mental health related to the condition of social isolation, confinement, loss of freedom and restriction of autonomy, pointed out by different studies, contributed to the understanding and discussion about the health risks of the psyche while facing the need for distance, quarantine and social isolation related to the prevention of coronavirus contagion.

Staying physically apart from those you love can be perceived by some people, especially by the elderly or those with vulnerable self-esteem and self-concept, as an experience of abandonment and loneliness, even though they know intellectually that these people are distant for protection, the prevention of COVID-19. The social distance and the feeling of boredom that this situation can provoke in people with self-love vulnerability, can generate the feeling of loss of meaning in being alive, which constitutes a risk of suicide. It was discussed the importance that family members of people diagnosed with a depressive syndrome, to supervise their family members' adherence to the treatment of the disease, as this condition may evolve into psychopathological manifestations that also represent a risk to the subject's integrity.

It was also observed that the deprivation of social interaction and the restriction of freedom that the need for the prevention of contagion implies, can represent for many people (especially those who have an immature personality), a real blow to their narcissism, an offense to the their free will due to the unconscious meaning that this experience can bring, this experience is perceived as the power castration they exercise or exercised over their lives. This feeling of castration tends to intensify in people whose childhood oedipal anguish and conflicts are still poorly elaborated, impairing the capacity for sanity that the prevention of COVID-19 requires.

It was also discussed about the risk of mental illness that predisposed people (genetically, psychologically, or impacted by traumatic childhood experiences) may suffer from the experience of social distancing, such as subjects who have an obsessive character or a pattern of insecurity to interact with people, or even schizoid traits, who respectively may develop, due to the prolonged social distance and the several cares related to hands, objects and environmental hygiene, the obsessive compulsive disorder, phobias (and other anxiety disorders such as post-stress disorder-traumatic and panic disorder) and syndromes that reflect the detriment in the ability to interact socially like Hikikomori.

It was listed as factors of protection to mental health in the circumstances of 
social distancing, isolation and quarantine, the affective proximity of family members, who can remain close even though physically separated, through telephone contacts and the internet, being the most important, showing interest in his relative who is physically distant or close and feeling distressed due to the deprivation of their freedom. Studies have pointed out that the feeling of empathy can favour the well-being of people in addition to promoting attitudes of care and protection for others.

This study can contribute as a theoretical tool for understanding the different behavioural manifestations that reflect the psychological suffering of the subjects who feel emotionally affected due to the need for social contacts restriction or the isolation itself, as well as bring scientific support to the prevention strategies for mental health and health psyche promotion, even in circumstances of quarantine or restriction and isolation from social interactions.

\section{Conflicts of Interest}

The authors declare no conflicts of interest regarding the publication of this paper.

\section{References}

Bion, W. (1972). Uma teoria do pensamento. Buenos Aires: Ed. Hormé.

Costa, G. Q., \& Gomes, G. (2017). Considerações sobre a causalidade psíquica e a escolha na psicanálise. Psicologia: Teoria e Pesquisa, 33, e33418.

https://doi.org/10.1590/0102.3772e33418

COVID-19 Daily Report from Johns Hopkins Medicine (2020). Coronavirus (COVID-19) Information and Updates. Johns Hopkins Medicine.

https://www.hopkinsmedicine.org/coronavirus/covid-19-daily-report.html

Daniel, F. C., Brites, A. P., Monteiro, R., \& Vicente, H. T. (2019). De "lar" abominado a estimado (ou tolerado): Reconfiguração das representações sobre institucionalização. Saúde e Sociedade, 28, 214-228. https://doi.org/10.1590/s0104-12902019180699

de Lima, C. V. C., Cândido, E. L., da Silva, J. A., Albuquerque, L. V., Soares, L. M., do Nascimento, M. M. et al. (2020). Effects of Quarantine on Mental Health of Populations Affected by Covid-19. Journal of Affective Disorders, 275, 253-254. https://doi.org/10.1016/j.jad.2020.06.063

Domingues-Castro, M. S., \& Torres, A. R. (2018). Hikikomori: Revisão sobre um grave fenômeno de isolamento social. Jornal Brasileiro de Psiquiatria, 67, 264-272. https://doi.org/10.1590/0047-2085000000214

Freud, A. (1977). O Ego e os mecanismos de defesa. Porto Alegre: Artmed.

Freud, S. (1905). Três Ensaios sobre a sexualidade. In Obras Completas de Sigmund Freud (pp. 1905-1989). Rio de Janeiro: Editora Imago.

Heidegger, M. (1927). Ser e tempo (Translated by Marcia Sa Cavalcante Schuback). Petropolis: Vozes.

Indursky, A. C., \& Conte, B. S. (2015). Trabalho psíquico do exílio: O corpo à prova da transição. Agora, 18, 273-288. https://doi.org/10.1590/S1516-14982015000200008

Klein, M. (1946). Notas sobre alguns mecanismos esquizoides. In Obras completas de Melanie Klein (pp. 1946-2012). Buenos Aires: Paidós. 
Klein, M. (2012). Amor, culpa e reparação. In Obras Completas de Melanie Klein (pp. 1921-1945). Buenos Aires: Paidós.

Lopes, A. P. A. T., Ganassin, G. S., Marcon, S. S., \& Decesaro, M. N. (2015). Abuso de bebida alcoólica e sua relação no contexto familiar. Estudos de Psicologia, 20, 22-30. https://doi.org/10.5935/1678-4669.20150004

Margaça, C., \& Rodrigues, D. (2019). Espiritualidade e resiliência na adultez e velhice: Uma revisão. Fractal: Revista de Psicologia, 31, 150-157. https://doi.org/10.22409/1984-0292/v31i2/5690

Mc Dougall, J. (1994). Corpo e linguagem: Da linguagem do soma às palavras da mente. The Revista Brasileira de Psicanálise, 28, 75-98.

Miguel, F. K., Hashimoto, E. S., Gonçalves, E. R. D. S., Oliveira, G. T., \& Wiltenburg, T. D. (2018). Estudos de validade do questionário online de empatia. Temas em Psicologia, 26, 2203-2216. https://doi.org/10.9788/TP2018.4-18Pt

Minayo, M. C. S., Teixeira, S. M. O., \& Martins, J. C. O. (2016). Tédio enquanto circunstância potencializadora de tentativas de suicídio na velhice. Estudos de Psicologia, 21, 36-45. https://doi.org/10.5935/1678-4669.20160005

Mukhtar, S. (2020). Psychological Health during the Coronavirus Disease 2019 Pandemic Outbreak. International Journal of Social Psychiatry, 66, 512-516. https://doi.org/10.1177/0020764020925835

Nietzsche, F. (2008). Aurora: Reflexões sobre os pensamentos morais (Translated by Paulo César Souza, pp. 1881-2004). São Paulo: Companhia das Letras.

Padovani, A. S., \& Ristum, M. (2016). Significados construídos acerca das instituições socioeducativas: Entre o imaginado e o vivido. Psico-USF, 21, 609-622. https://doi.org/10.1590/1413-82712016210314

Santos, W. A., Fuly, P. S. C., Santos, M. L. S. C., Souto, M. D., Reis, C. M., \& Beretta, L. L. (2017). Evidências sobre o isolamento social em pacientes com exsudato em feridas neoplásicas: Revisão integrativa. Revista Enfermagem Atual, 81, 89-96. https://revistaenfermagematual.com/index.php/revista/article/view/326

Schmid, P. C. (2019). Saúde mental e restrição de liberdade: Relato de experiência como médica psiquiatra em centro de detenção de refugiados. Saúde Debate, 43, 626-635. https://doi.org/10.1590/0103-1104201912126

Segal, H. (1975). Introdução à obra de Melanie Klein. Rio de Janeiro: Imago.

Seidl-De-Moura, M. L., Pessoa, L., Mendes, D. M. L. F., Ramos, D. O., Fioravanti-Bastos, A. C. M., Carvalho, R. V. C. et al. (2017). Concepções sobre autonomia em faixas etárias diversas. Estudos de Psicologia, 34, 293-303. https://doi.org/10.1590/1982-02752017000200010

Smith, B. J., \& Lim, M. H. (2020). How the COVID-19 Pandemic Is Focusing Attention on Loneliness and Social Isolation. Public Health Research and Practice, 30, e3022008. https://doi.org/10.17061/phrp3022008

Telessaúde, R. S. (2020). Electronic Newspaper at Universidade Federal do Rio Grande do Sul (UFRGS). https://www.ufrgs.br/telessauders

World Health Organization (2020). Coronavirus Disease (COVID-19) Pandemic. https://www.who.int/emergencies/diseases/novel-coronavirus-2019 